\title{
Cytotoxic sesquiterpenoids MBJ-0009 and MBJ-0010 from a saprobic fungus Nectria sp. f26111
}

\author{
Teppei Kawahara ${ }^{1}$, Masashi Itoh ${ }^{2}$, Miho Izumikawa ${ }^{1}$, Noriaki Sakata ${ }^{2}$, Toshio Tsuchida ${ }^{2}$ and Kazuo Shin-ya ${ }^{3}$
}

The Journal of Antibiotics (2013) 66, 567-569; doi:10.1038/ja.2013.45; published online 8 May 2013

Keywords: cytotoxicity; Nectria; sesquiterpenoid

During our screening program for novel microbial metabolites using the advanced compound-identification system designated as 'MBJ's special selection', we succeeded in the discovery of new natural compounds. $^{1,2}$ Among them, ester-substituted sesquiterpenoids related to the eremophilane class MBJ-0009 (1) and MBJ-0010 (2) were isolated from a fungus Nectria sp. f26111 (Figure 1). These type of compounds isolated from fungal cultures have been reported as cytotoxic, $^{3-5}$ antimalarial $^{5}$ agents and cell-adhesion inhibitors. ${ }^{6}$ Here, we report the fermentation, isolation, structure elucidation and brief biological activity of $\mathbf{1}$ and 2 .

The fungus Nectria sp. f26111 was isolated from a soil sample collected in Kochi Prefecture, Japan. The strain was cultivated in 250-ml Erlenmeyer flasks, each containing $25 \mathrm{ml}$ of a seed medium consisting of $2 \%$ potato starch (Tobu Tokachi Nosan Kako Agricultural Cooperative Assoc., Hokkaido, Japan), 1\% glucose (Junsei Chemical, Tokyo, Japan), 2\% soybean powder (Honen SoyPro, J-Oil Mills, Tokyo, Japan), $0.1 \% \mathrm{KH}_{2} \mathrm{PO}_{4}$ and $0.05 \% \mathrm{MgSO}_{4} \cdot 7 \mathrm{H}_{2} \mathrm{O}$. The flasks were shaken on a rotary shaker $(220$ r.p.m. $)$ at $25{ }^{\circ} \mathrm{C}$ for 3 days. Aliquots $(0.5 \mathrm{ml})$ of the broth were transferred to $500-\mathrm{ml}$ Erlenmeyer flasks containing $50 \mathrm{ml}$ of a production medium consisting of $2 \%$ potato starch (Tobu Tokachi Nosan Kako Agricultural Cooperative Assoc.), $1 \%$ glucose (Junsei Chemical), 2\% soybean powder (Honen SoyPro, J-Oil Mills), $0.1 \% \mathrm{KH}_{2} \mathrm{PO}_{4}$ and $0.05 \%$ $\mathrm{MgSO}_{4} \cdot 7 \mathrm{H}_{2} \mathrm{O}$, and cultured on a rotary shaker $\left(220\right.$ r.p.m.) at $25^{\circ} \mathrm{C}$ for 4 days. As our routine step, the fermentation broth (2l) was directly extracted with an equal volume of $n$ - $\mathrm{BuOH}$.

The crude extract was then partitioned between EtOAc $(300 \mathrm{ml} \times 3)$ and $\mathrm{H}_{2} \mathrm{O}(300 \mathrm{ml})$ to yield EtOAc extract $(730 \mathrm{mg})$. The obtained extract was applied to a silica gel medium-pressure liquid chromatography column (Purif-Pack SI-30; Shoko Scientific Co., Ltd, Yokohama, Japan) and eluted with a gradient system of hexane-EtOAc (0-25\% EtOAc) followed by the stepwise solvent system of $\mathrm{CHCl}_{3}-\mathrm{MeOH}(0,1,2,5,10,20,30$ and $100 \% \mathrm{MeOH})$. The $2 \% \mathrm{MeOH}$ eluate $(200 \mathrm{mg})$ was subjected to octadecylsilanemedium-pressure liquid chromatography (Purif-Pack octadecylsilane-
30; Shoko Scientific Co., Ltd) by using the stepwise solvent system (50, 60, 70, 80, 90 and 100\% aqueous $\mathrm{MeOH})$. The $90 \% \mathrm{MeOH}$ fraction $(127 \mathrm{mg}$ ) was purified by reversed-phase HPLC using a CAPCELL PAK C18 MGII column $(5.0 \mu \mathrm{m}, 20$ i.d. $\times 150 \mathrm{~mm}$; Shiseido, Tokyo, Japan) with $70 \%$ aqueous $\mathrm{CH}_{3} \mathrm{CN}$ containing $0.1 \%$ formic acid (flow rate: $10 \mathrm{ml} \mathrm{min}^{-1}$ ) to yield $1(57.4 \mathrm{mg}$, retention time $(\mathrm{Rt})=21.7 \mathrm{~min})$ and crude $2(8.5 \mathrm{mg}, \mathrm{Rt}=19.8 \mathrm{~min})$. The repetitive HPLC purification of $2(3.0 \mathrm{mg}, \mathrm{Rt}=19.8 \mathrm{~min})$ from the crude material containing 2 was carried out using the same procedure as 1 .

MBJ-0009 (1) was isolated as a pale yellow amorphous powder: $[\alpha]^{24}{ }_{\mathrm{D}}-10$ (c 0.70, MeOH); UV $\lambda_{\max } \mathrm{nm}(\varepsilon): 340$ (15 000) in $\mathrm{MeOH}$; IR (attenuated total reflectance) $v_{\max } \mathrm{cm}^{-1}: 3400$ (hydroxy), 1747 (aliphatic ester carbonyl) and 1720 (unsaturated ester carbonyl). Its molecular formula was determined as $\mathrm{C}_{31} \mathrm{H}_{42} \mathrm{O}_{8}$ by negative ion highresolution ESI MS $\left(m / z 541.2767[\mathrm{M}-\mathrm{H}]^{-}\right.$, calculated for $\mathrm{C}_{31} \mathrm{H}_{41} \mathrm{O}_{8}$ : $\mathrm{m} / z$ 541.2801). The planar structure was determined by the series of 2D NMR analyses, including DQF-COSY, HSQC, and constant-time $\mathrm{HMBC}^{7}$ (CT-HMBC) spectra (Figure 1a). The ${ }^{13} \mathrm{C}$ and ${ }^{1} \mathrm{H}$ NMR data for $\mathbf{1}$ are listed in Table 1 .

The DQF-COSY spectrum of $\mathbf{1}$ allowed ${ }^{1} \mathrm{H}$ coupling networks from an oxygenated methine proton $\mathrm{H}-1\left(\delta_{\mathrm{H}} 4.54\right)$ through an oxygenated methine proton $\mathrm{H}-2\left(\delta_{\mathrm{H}} 5.10\right)$ to methylene protons $\mathrm{H}_{2}-3$ $\left(\delta_{\mathrm{H}} 2.40,2.03\right)$, and between methylene protons $\mathrm{H}_{2}-6\left(\delta_{\mathrm{H}} 2.06\right.$ and 1.36) and a methine proton $\mathrm{H}-7 \quad\left(\delta_{\mathrm{H}} 2.61\right)$. In the CT-HMBC spectrum, ${ }^{1} \mathrm{H}-{ }^{13} \mathrm{C}$ long-range correlations from a methyl proton $\mathrm{H}_{3}-15\left(\delta_{\mathrm{H}} 1.18\right)$ to a methylene carbon C-3 $\left(\delta_{\mathrm{C}} 34.9\right)$ and quaternary carbons $\mathrm{C}-4\left(\delta_{\mathrm{C}} 74.6\right)$ and $\mathrm{C}-5\left(\delta_{\mathrm{C}} 39.8\right)$, and from $\mathrm{H}-1$ and $\mathrm{H}-2$ to an oxygenated quaternary carbon $\mathrm{C}-10\left(\delta_{\mathrm{C}} 60.7\right)$ were observed. The presence of a 1,2,3,5-tetraoxygenated cyclohexane ring moiety was revealed by long-range couplings from a methyl proton $\mathrm{H}_{3}-14$ $\left(\delta_{\mathrm{H}} 1.27\right)$ to $\mathrm{C}-4, \mathrm{C}-5$ and $\mathrm{C}-10$. The additional couplings from $\mathrm{H}_{3}-14$ to a methylene carbon C-6 $\left(\delta_{\mathrm{C}} 30.9\right)$ and from an oxygenated methine proton $\mathrm{H}-9\left(\delta_{\mathrm{H}} 3.30\right)$ to $\mathrm{C}-1, \mathrm{C}-10, \mathrm{C}-5$, a methine carbon C-7 $\left(\delta_{\mathrm{C}} 44.3\right)$ and a ketal carbon $\mathrm{C}-8\left(\delta_{\mathrm{C}}\right.$ 102.1) indicated the

\footnotetext{
1Japan Biological Informatics Consortium (JBIC), Tokyo, Japan; ${ }^{2}$ Bioresource Laboratories, MicroBiopharm Japan (MBJ), Iwata, Shizuoka, Japan and ${ }^{3}$ National Institute of Advanced Industrial Science and Technology (AIST), Tokyo, Japan

Correspondence: Dr K Shin-ya, National Institute of Advanced Industrial Science and Technology (AIST), 2-4-7 Aomi, Koto-ku, Tokyo, Japan.

E-mail: k-shinya@aist.go.jp
}

Received 5 February 2013; accepted 15 April 2013; published online 8 May 2013 
<smiles>C=C1COC2(O)C1CC13OC14C(OC(=O)/C=C/C=C/C=C/C(C)=C/C(C)CC)C(OC(C)=O)CC(C)(O)C4(C)CC23</smiles>

MBJ-0009 (1): 4'E MBJ-0010 (2): 4'Z

b

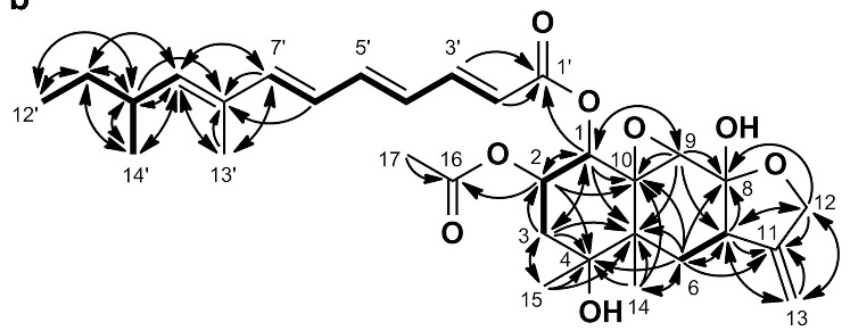

C



Figure 1 (a) Structures of 1 and 2. (b) Key COSY and HMBC correlations of 1. COSY: bold line; HMBC $\left({ }^{1} \mathrm{H}\right.$ to $\left.{ }^{13} \mathrm{C}\right)$ : arrow. (c) Key NOESY correlations of 1 .

presence of an additional 1,1,2,3-tetraoxygenated cyclohexane ring moiety (C-5 to C-10). HMBC correlations from exomethylene protons $\mathrm{H}_{2}-13\left(\delta_{\mathrm{H}} 4.96\right.$ and $\left.4.94, \delta_{\mathrm{C}} 105.2\right)$ to C-7, an olefinic quaternary carbon $\mathrm{C}-11\left(\delta_{\mathrm{C}} 150.2\right)$ and an oxygenated methylene carbon $\mathrm{C}-12\left(\delta_{\mathrm{C}} 69.9\right)$ and from $\mathrm{H}_{2}-12\left(\delta_{\mathrm{H}} 4.57\right.$ and 4.50$)$ to $\mathrm{C}-8$ indicated the presence of a 3-methylenetetrahydrofuran moiety. The high-fielded chemical shifts of C-9 $\left(\delta_{\mathrm{C}} 58.7\right)$ and C-10 are considered to form an epoxide ring at these carbons, and consequently the C-8 is a hemiketal carbon. A methyl proton $\mathrm{H}_{3}-17\left(\delta_{\mathrm{H}} 2.08\right)$ and $\mathrm{H}-2$ were ${ }^{1} \mathrm{H}-{ }^{13} \mathrm{C}$ long-range coupled to a carbonyl ketone carbon $\mathrm{C}-16\left(\delta_{\mathrm{C}}\right.$ 169.2), which suggested the presence of an acetoxy group at the C-2 position. Thus, the structure of the sesquiterpenoid substructure of 1 was determined as shown in Figure 1b. The other substructure was determined as follows. In the DQF-COSY spectrum, the presence of an anteisopentane moiety was revealed by ${ }^{1} \mathrm{H}-{ }^{1} \mathrm{H}$ couplings from a terminal methyl proton $\mathrm{H}_{3}-12^{\prime}\left(\delta_{\mathrm{H}} 0.82\right)$ through aliphatic methylene protons $\mathrm{H}_{2}-11^{\prime}\left(\delta_{\mathrm{H}} 1.38\right.$ and 1.26$)$ to an allylic methine proton $\mathrm{H}-10^{\prime}$ $\left(\delta_{\mathrm{H}} 2.41\right)$, which was also spin coupled to both a doublet methyl proton $\mathrm{H}_{3}-14^{\prime}\left(\delta_{\mathrm{H}} 0.95\right)$ and an olefinic methine proton $\mathrm{H}-9^{\prime}$ $\left(\delta_{\mathrm{H}} 5.42\right)$. The sequence from an olefinic proton $\mathrm{H}-2^{\prime}\left(\delta_{\mathrm{H}} 5.80\right)$ to an olefinic proton $\mathrm{H}-7^{\prime}\left(\delta_{\mathrm{H}} 6.44\right)$ through olefinic protons $\mathrm{H}-3^{\prime}$ $\left(\delta_{\mathrm{H}} 7.32\right), \mathrm{H}-4^{\prime}\left(\delta_{\mathrm{H}} 6.29\right), \mathrm{H}-5^{\prime}\left(\delta_{\mathrm{H}} 6.64\right)$ and $\mathrm{H}-6^{\prime}\left(\delta_{\mathrm{H}} 6.21\right)$ suggested the presence of a hexatriene moiety. In addition to these two proton sequences, HMBC correlations from a methyl proton
Table $1{ }^{13} \mathrm{C}$ and ${ }^{1} \mathrm{H}$ NMR spectroscopic data for MBJ-0009 (1) and MBJ-0010 (2)

\begin{tabular}{|c|c|c|c|c|}
\hline \multirow[b]{2}{*}{ Position } & \multicolumn{2}{|r|}{$1^{a}$} & \multicolumn{2}{|r|}{$2^{b}$} \\
\hline & $\delta_{\mathrm{C}}$ & $\delta_{\mathrm{H}}$, mult $(J$ in $\mathrm{Hz})$ & $\delta_{\mathrm{C}}$ & $\delta_{\mathrm{H}}$, mult $(\mathrm{J}$ in $\mathrm{Hz})$ \\
\hline 1 & 72.4 & $4.54, \mathrm{dd}(2.0,2.6)$ & 72.5 & 4.58, br s \\
\hline 2 & 70.6 & $5.10, \operatorname{ddd}(2.6,2.6,3.7)$ & 70.5 & $\begin{array}{l}5.11 \text {, ddd }(2.5,3.5 \text {, } \\
3.5)\end{array}$ \\
\hline 3 & 34.9 & $\begin{array}{l}2.40, \text { dd }(3.7,15.7) \\
2.03, \text { ddd }(2.0,2.6,15.7)\end{array}$ & 34.9 & $\begin{array}{l}2.40, \mathrm{dd}(3.5,16.0) \\
2.03, \mathrm{dd}(3.5,16.0)\end{array}$ \\
\hline 4 & 74.6 & & 74.6 & \\
\hline 5 & 39.8 & & 39.8 & \\
\hline 6 & 30.9 & $\begin{array}{l}2.06, \mathrm{dd}(13.6,13.6) \\
1.36, \mathrm{dd}(6.3,13.6)\end{array}$ & 30.9 & $\begin{array}{l}\text { 2.08, ov } \mathrm{l}^{\mathrm{C}} \\
1.38, \mathrm{ovl}^{\mathrm{c}}\end{array}$ \\
\hline 7 & 44.3 & $\begin{array}{l}2.61, \text { dddd }(1.8,1.8,6.3 \\
13.6)\end{array}$ & 44.3 & $2.63, \mathrm{dd}(6.0,13.5)$ \\
\hline 8 & 102.1 & & 102.1 & \\
\hline 9 & 58.7 & $3.30, \mathrm{~s}$ & 58.2 & $3.24, \mathrm{~s}$ \\
\hline 10 & 60.7 & & 60.8 & \\
\hline 11 & 150.2 & & 150.0 & \\
\hline 12 & 69.9 & $\begin{array}{l}4.57, \text { ddd }(2.3,4.1,12.6) \\
4.50, \text { ddd }(2.1,4.1,12.6)\end{array}$ & 70.1 & $\begin{array}{l}\text { 4.58, ovl }{ }^{\mathrm{C}} \\
4.52, \mathrm{ovl}^{\mathrm{C}}\end{array}$ \\
\hline 13 & 105.2 & $\begin{array}{l}4.96, d d(2.0,4.1) \\
4.94, d d(2.3,4.1)\end{array}$ & 105.4 & $\begin{array}{l}\text { 4.99, dd }(2.0,4.0) \\
4.97, \mathrm{dd}(2.0,4.0)\end{array}$ \\
\hline 14 & 21.00 & $1.27, \mathrm{~s}$ & 21.1 & $1.30, \mathrm{~s}$ \\
\hline 15 & 23.3 & $1.18, \mathrm{~s}$ & 23.3 & $1.18, \mathrm{~s}$ \\
\hline 16 & 169.2 & & 169.2 & \\
\hline 17 & 21.12 & $2.08, \mathrm{~s}$ & 21.2 & $2.09, \mathrm{~s}$ \\
\hline $1^{\prime}$ & 165.2 & & 165.3 & \\
\hline $2^{\prime}$ & 117.9 & $5.80, \mathrm{~d}(15.0)$ & 118.7 & $5.84, d(15.5)$ \\
\hline $3^{\prime}$ & 146.7 & 7.32, dd $(11.4,15.0)$ & 141.5 & $7.85, \mathrm{dd}(11.0,15.5)$ \\
\hline $4^{\prime}$ & 128.1 & $6.29, \mathrm{dd}(11.4,14.7)$ & 124.4 & $6.04, \mathrm{dd}(11.0,11.0)$ \\
\hline $5^{\prime}$ & 143.2 & $6.64, \mathrm{dd}(10.9,14.7) \mathrm{h}$ & 139.7 & $6.42, \mathrm{dd}(11.0,11.0)$ \\
\hline $6^{\prime}$ & 125.2 & $6.21, \mathrm{dd}(10.9,15.2)$ & 120.6 & $6.65, \mathrm{dd}(11.0,14.5)$ \\
\hline $7^{\prime}$ & 143.7 & $6.44, d(15.2)$ & 143.8 & $6.43, d(14.5)$ \\
\hline $8^{\prime}$ & 132.7 & & 132.7 & \\
\hline $9^{\prime}$ & 144.0 & $5.42, d(9.7)$ & 144.3 & 5.44, br d (9.5) \\
\hline $10^{\prime}$ & 34.7 & $2.41, \mathrm{ovl}^{\mathrm{c}}$ & 34.8 & $2.43, \mathrm{ovl}^{\mathrm{C}}$ \\
\hline $11^{\prime}$ & 30.2 & $\begin{array}{l}1.38, \mathrm{ovl}^{\mathrm{C}} \\
1.26, \mathrm{ovl} \mathrm{C}^{\mathrm{C}}\end{array}$ & 30.2 & $\begin{array}{l}1.39, \mathrm{ov}^{\mathrm{c}} \\
1.26, \mathrm{ov}^{\mathrm{c}}\end{array}$ \\
\hline $12^{\prime}$ & 11.9 & $0.82, \mathrm{t}(7.2)$ & 12.0 & $0.84, t(7.5)$ \\
\hline $13^{\prime}$ & 12.5 & $1.77, \mathrm{~s}$ & 12.7 & $1.82, \mathrm{~d}(1.0)$ \\
\hline $14^{\prime}$ & 20.4 & $0.95, d(6.7)$ & 20.4 & $0.95, d(8.5)$ \\
\hline
\end{tabular}

${ }^{a} 600 \mathrm{MHz}$.

b500 MHz. NMR spectra were taken on a Varian NMR System 500 NB CL (1) or 600 NB CL (2) in $\mathrm{CDCl}_{3}$ with the residual solvent peak as an internal standard $\left(\delta_{\mathrm{C}} 77.0, \delta_{\mathrm{H}} 7.25\right.$ p.p.m.) 'Overlapped with other signals.

$\mathrm{H}_{3}-13^{\prime}\left(\delta_{\mathrm{H}} 1.77\right)$ to an olefinic methine carbon $\mathrm{C}-7^{\prime}\left(\delta_{\mathrm{C}} 143.7\right)$, an olefinic quaternary carbon C- $8^{\prime}\left(\delta_{\mathrm{C}} 132.7\right)$ and $\mathrm{C}-9^{\prime}\left(\delta_{\mathrm{C}} 144.0\right)$ indicated the connectivity between two partial structures through the olefinic quaternary carbon C-8 ${ }^{\prime}$. Finally, the planar structure of 1 was determined by $\mathrm{HMBC}$ correlations from $\mathrm{H}-1, \mathrm{H}-2^{\prime}$ and $\mathrm{H}-3^{\prime}$ to a carbonyl ketone carbon $\mathrm{C}-1^{\prime}\left(\delta_{\mathrm{C}} 165.2\right)$, which suggested an ester linkage between $\mathrm{C}-1$ and $\mathrm{C}-2^{\prime}$, as shown in Figure 1b. The large vicinal $J$ values between $\mathrm{H}-2^{\prime}$ and $\mathrm{H}-3^{\prime}, \mathrm{H}-4^{\prime}$ and $\mathrm{H}-5^{\prime}$, and $\mathrm{H}-6^{\prime}$ and $\mathrm{H}-7^{\prime}(15.0,14.7$ and $15.2 \mathrm{~Hz}$, respectively) suggested that the geometries of the position at $\mathrm{C}-2^{\prime}, \mathrm{C}-4^{\prime}$ and $\mathrm{C}-6^{\prime}$ were in all $E$ geometries. The chemical shift of C-13' $\left(\delta_{\mathrm{C}} 12.5\right)$ and a NOESY correlation between $\mathrm{H}-\mathrm{7}^{\prime}$ and $\mathrm{H}-\mathrm{9}^{\prime}$ also suggested an $E$ geometry of the olefinic bond at C-8'. 
The relative configuration of the sesquiterpenoid moiety was established from the NOESY spectrum and the corresponding coupling constants. A large coupling constant $(13.6 \mathrm{~Hz})$ between H-6ax $\left(\delta_{\mathrm{H}} 2.06\right)$ and $\mathrm{H}-7\left(\delta_{\mathrm{H}} 2.61\right)$ established that these protons are in diaxial orientation. In the NOESY spectrum, NOEs among H-7, $\mathrm{H}_{3}-14$ and $\mathrm{H}-3 \mathrm{ax}\left(\delta_{\mathrm{H}} 2.40\right)$ allowed that $\mathrm{H}-7, \mathrm{H}-3 \mathrm{ax}$ and $\mathrm{C}-14$ are located on the same direction of the molecule. Small coupling constants between $\mathrm{H}-1$ and $\mathrm{H}-2(2.6 \mathrm{~Hz})$, and between $\mathrm{H}-2$ and both protons of $\mathrm{H}_{2}-3$ ( 2.6 and $3.7 \mathrm{~Hz}$, respectively) indicated that $\mathrm{H}-2$ is in an equatorial location. As an NOE between $\mathrm{H}-1$ and $\mathrm{H}-3$ ax was not observed, $\mathrm{H}-1$ is concluded to be in an equatorial location. The existence of NOE between $\mathrm{H}_{3}-15$ and $\mathrm{H}-6 \mathrm{eq}\left(\delta_{\mathrm{H}} 1.36\right)$ suggested that a hydroxy group at C-4 is in an axial orientation. Furthermore, an axial orientation of a hydroxy residue at C-8 was revealed by NOESY correlations among $\mathrm{H}-13\left(\delta_{\mathrm{H}} 4.94\right), \mathrm{H}-7$ and $\mathrm{H}-6$ eq. Although an NOESY correlation between $\mathrm{H}-1$ and $\mathrm{H}-9$ was observed, the relative configuration at $\mathrm{C}-10$ could not be determined. Thus, the partial relative configuration of $\mathbf{1}$ was elucidated as shown in Figure 1c.

MBJ-0010 (2) was isolated as a pale yellow amorphous powder: $[\alpha]^{24}+18$ (c 0.15, MeOH); UV $\lambda_{\max } \mathrm{nm}(\varepsilon): 340(17,000)$ in $\mathrm{MeOH}$; IR (attenuated total reflectance) $v_{\max } \mathrm{cm}^{-1}: 3400$ (hydroxy), 1747 (aliphatic ester carbonyl) and 1716 (unsaturated ester carbonyl). The molecular formula of 2 was led to be $\mathrm{C}_{31} \mathrm{H}_{42} \mathrm{O}_{8}$ from the negative HRESIMS ion peak at $m / z 541.2791$ calculated for $\mathrm{C}_{31} \mathrm{H}_{41} \mathrm{O}_{8}$. The UV and IR spectra of $\mathbf{2}$ were very similar to those of $\mathbf{1}$. Furthermore, the ${ }^{1} \mathrm{H}$ and ${ }^{13} \mathrm{C}$ NMR data and obtained planar structure of 2 were the same as 1. A difference was found in the coupling constant between $\mathrm{H}-4^{\prime}$ and $\mathrm{H}-5^{\prime}(11.0 \mathrm{~Hz})$ revealing the geometry of $4^{\prime} Z$, and hence, the structure of 2 was determined as shown in Figure 1a.

The obtained structures of $\mathbf{1}$ and $\mathbf{2}$ were structurally related to cytotoxic compounds berkleasmins isolated from saprophytic fungus
Berkleasmium nigroapicale. ${ }^{5}$ The cytotoxic activities of $\mathbf{1}$ and $\mathbf{2}$ against human ovarian adenocarcinoma SKOV-3 cells were examined by using the WST-8 [(2-(2-methoxy-4-nitrophenyl)-3-(4-nitrophenyl)5-(2,4-disulfophenyl)-2H-tetrazolium, monosodium salt] colorimetric assay (Cell Counting Kit; Dojindo, Kumamoto, Japan). After $72 \mathrm{~h}$ of treatment, 1 and 2 exhibited moderate cytotoxicity with the $\mathrm{IC}_{50}$ values of 24.7 and $11.2 \mu \mathrm{M}$, respectively.

\section{ACKNOWLEDGEMENTS}

This work was supported by a grant from the New Energy and Industrial Technology Department Organization (NEDO) of Japan, and a Grant-in-Aid for Scientific Research (23380067 to K.S.) from the Japan Society for the Promotion of Science (JSPS).

1 Kawahara, T. et al. Three eremophilane derivatives, MBJ-0011, MBJ-0012 and MBJ-0013, from an endophytic fungus Apiognomonia sp. f24023. J. Antibiot. 66, 299-302 (2013).

2 Izumikawa, M. et al. Correction of the structure of cuevaene A and its identity with MBJ-0020 from Streptomyces sp. 30503. J. Antibiot. 66, 563-565 (2013).

3 Huang, Y. F., Qiao, L., Lv, A. L., Pei, Y. H. \& Tian, L. Eremophilane sesquiterpenes from the marine fungus Penicillium sp. BL27-2. Chin. Chem. Lett. 19, 562-564 (2008).

4 Oh, H. et al. Cryptosphaerolide, a cytotoxic Mcl-1 inhibitor from a marine-derived ascomycete related to the genus. Cryptosphaeria. J. Nat. Prod. 73, 998-1001 (2010).

5 Isaka, M., Srisanoh, U., Veeranondha, S., Choowong, W. \& Lumyong, S. Cytotoxic eremophilane sesquiterpenoids from the saprobic fungus Berkleasmium nigroapicale BCC 8220. Tetrahedron 65, 8808-8815 (2009).

6 Yamada, T., Iritani, M., Minoura, K., Kawai, K. \& Numata, A. Peribysins A-D, potent cell-adhesion inhibitors from a sea hare-derived culture of Periconia species. Org. Biomol. Chem. 2, 2131-2135 (2004).

7 Furihata, K. \& Seto, H. Constant time HMBC (CT-HMBC), a new HMBC technique useful for improving separation of cross peaks. Tetrahedron Lett. 39, 7337-7340 (1998). 